\title{
GERAKAN OPINI DIGITAL \#TRUEBEAUTY PADA TWITTER UNTUK PEMERAN FILM ADAPTASI KOMIK WEBTOON
}

\author{
Joanne Tjahyana \\ Universitas Kristen Petra
}

\begin{abstract}
Digital Movement of Opinion (DMO) using hashtag \#TrueBeauty on Twitter was conducted by the fans of True Beauty as one of the most popular Webtoon's comic. The fans gave their opinion about the perfect cast for the movie adaption of the comic. The objective of this research is to analyse the network that was formed by the DMO of \#TrueBeauty. The method that had been used was social network analysis and the datasets mining was done using Netlytic. This research indicates that fans as the actors of the DMO were spreaded widely across the network and not centralized into certain dominant actors. The actors was divided into different clusters and every cluster has its own characteristics based on different locations and cultures. Therefore the role of influencers or dominant actors in every cluster is very important to deliver opinions with a style that suits every community. Moreover, text analysis found that film industry should pay attention to social media opinion, because many of the opinion were reflects the original desires of every fan without any intermediaton from any parties.
\end{abstract}

\author{
Keywords \\ Digital Movement of Opinion, \\ Hashtags, Webtoon, Netlytic, \\ Social Network Analysis.
}

Correspondence Contact joanne@petra.ac.id

\section{PENDAHULUAN}

Tagar pada media sosial dapat digunakan oleh khalayak untuk menyampaikan opini mereka secara bebas tanpa mediasi berbagai pihak (Barisione \& Ceron, 2017). Antelmi, Breslin, \& Young (2018) menyatakan bahwa industri perfilman juga dapat menggunakan tagar untuk mengetahui opini dari fans atau penonton setia film tersebut. Tagar yang digunakan oleh para penonton sebuah film biasanya merupakan judul dari film tersebut atau nama dari karakter yang ada pada film. Ranjan \& Sood (2018) menyatakan bahwa rekomendasi - rekomendasi penonton yang ada pada media sosial sangatlah berpengaruh terhadap kesuksesan dari sebuah industri perfilman. Rekomendasi - rekomendasi ini dapat meliputi jalan cerita hingga aktor yang berperan pada sebuah film.

Saat ini terdapat sebuah layanan komik daring asal Korea, yaitu Webtoon telah meraih sukses baik di Korea maupun di dunia ("Popular Mobile Webcomic Service, LINE Webtoon, Debuts in the United States and Worldwide-MarketWatch," 2014). Webtoon yang telah menerbitkan 2600 judul komik original dan memiliki lebih dari 15 juta pembaca setia harinya ini telah menjadi fenomena tersendiri dengan menyajikan cara membaca komik daring yang mudah melalui aplikasi ponsel. Kesuksesan Webtoon tersebut membuat banyak industri hiburan lainnya seperti industri perfilman untuk membuat film berdasarkan judul - judul komik yang meraih sukses dengan jutaan subscribers pada Webtoon (Tantimedh, 2019). Pada tahun 2019 yang lalu telah terdapat 24 judul film drama yang sukses diadaptasi dari komik daring Webtoon seperti "What's Wrong With Secretary Kim" dan "My ID is Gangnam Beauty" ("24 Dramas Of 2019 Based On Webtoon," 2019). Sedangkan untuk tahun 2020 telah terdapat 15 judul film drama yang akan diadaptasi dari komik daring Webtoon ("15 Dramas Of 2020 Based On Webtoon-Confirmed," 2020). 
Salah satu judul komik daring pada Webtoon yang telah meraih kesuksesan dan telah dikonfirmasi akan diproduksi menjadi film drama Korea adalah True Beauty. Komik daring yang ditulis oleh Yaongyi adalah salah satu judul paling populer pada Webtoon dan selalu menduduki peringkat tiga gesar untuk genre komik drama pada berbagai bahasa. Komik True Beauty bercerita tentang seorang gadis bernama Im JuGyung yang memiliki wajah yang jelek namun berubah menjadi sangat cantik seperti seorang dewi ketika menggunakan make up. Plot cerita menjadi lebih seru dengan bumbu romantisme yang menghadirkan dua orang pria tampan yaitu Lee SuHo dan Han SeoJoon ("Find Out Koreans Desired Cast For Adaptation Of Popular Webtoon 'True Beauty,'” 2019).

Produksi film drama True Beauty ini akan dimulai pada tahun 2020, dan saat ini para pembaca sedang ramai memperbincangkan rencana produksi film tersebut di media sosial. Untuk meramaikan perbincangan penggemar, akun resmi Webtoon pada media sosial Twitter @Webtoon juga melontarkan pertanyaan kepada para penggemar mengenai cast dari drama tersebut. Adapun isi posting tersebut adalah "What's Your Movie Dream Cast for \#TrueBeauty?" seperti yang terlihat pada Gambar 1. Tagar \#TrueBeauty adalah tagar yang paling populer digunakan oleh Webtoon dan para penggemar.

Gambar 1. Tweet @Webtoon Untuk Dream Cast \#TrueBeauty

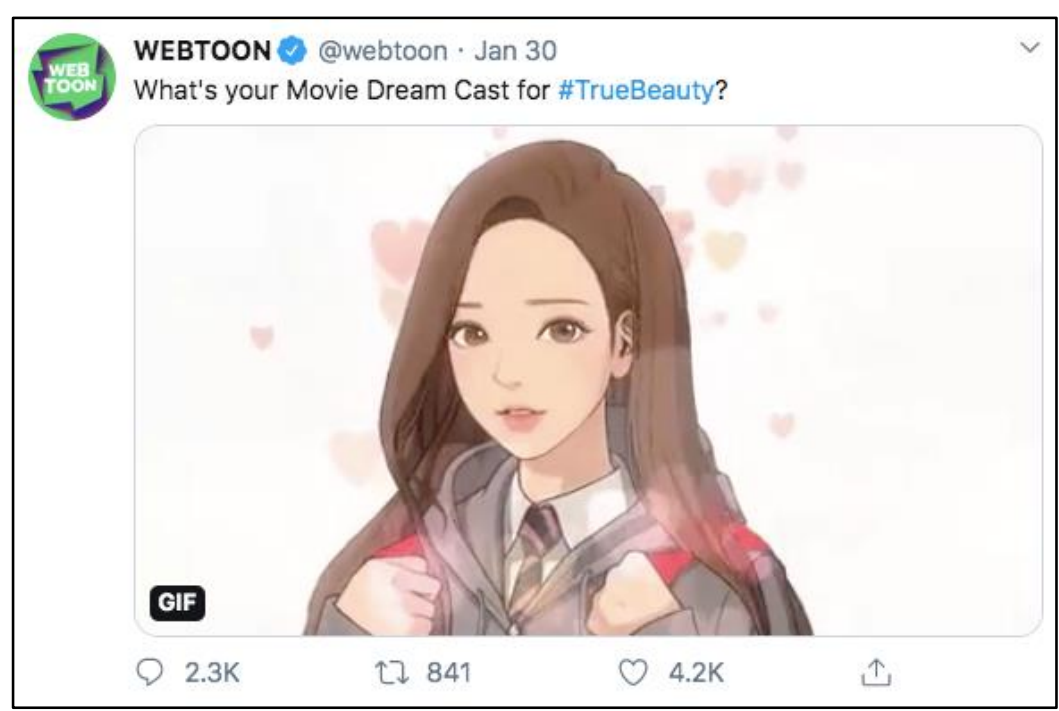

Sumber: Twitter.com/webtoon

Penelitian ini ingin melihat bagaimana gerakan opini digital atau Digital Movement of Opinion (DMO) melalui jaringan komunikasi tagar \#TrueBeauty pada Twitter. Selanjutnya penelitian ini juga akan mengamati topik yang ramai diperbincangkan terkait tagar \#TrueBeauty.

\section{KAJIAN TEORITIK}

\section{Gerakan Opini Digital (Digital Movements of Opinion / DMO)}

Pada era komunikasi digital, konsep dari opini publik dan aksi gerakan sosial mengalami perubahan dari konsep tradisional yang memerlukan adanya organisasi yang melakukan intermediasi proses pengumpulan data (polling dan survey) serta organisasi yang mewadahi sebuah gerakan sosial (organisasi sosial, politik, dan lainnya). Dengan adanya media sosial, maka publik dapat menyampaikan opininya tentang suatu topik atau permasalahan dengan mudah tanpa melalui sebuah perantara organisasi (Barisione \& Ceron, 2017). 
Selanjutnya media sosial tidak hanya menjadi tempat untuk menyampaikan opini, namun juga berlanjut menjadi tempat diskusi publik dan sarana untuk menyuarakan sebuah pesan secara kolektif. Gerakan opini digital pada media sosial cenderung bersifat spontan dan menjadi penyalur ekspresi dari para pengguna media sosial. Opini yang disampaikan melalui media sosial juga bersifat sementara dan disampaikan oleh publik yang sedang aktif bereaksi terhadap sebuah permasalahan, serta seringkali dipicu oleh respon yang emosional. Opini yang disampaikan melalui media sosial juga sama pentingnya dengan opini yang didapatkan secara formal dan tradisional melalui lembaga atau organisasi survey serta dapat dihitung dan diklasifikasi menggunakan analisis teks seperti misalnya untuk mengetahui sentimen publik terhadap sebuah isu atau permasalahan (Barisione \& Ceron, 2017).

Tagar Dalam Gerakan Opini Digital Pada Industri Perfilman

Tagar telah menjadi penghubung antar pengguna media sosial sehingga membentuk sebuah jaringan komunikasi (Bernard, 2019). Terdapat beberapa motivasi yang mendorong pengguna untuk menggunakan tagar ketika menyampaikan opini pada media sosial, diantaranya adalah reaching, endorsing trendgaging dan bonding (Rauschnabel, Sheldon, \& Herzfeldt, 2019). Di dalam dunia hiburan khususnya industri perfilman, tagar seringkali digunakan oleh para penggemar sebuah film untuk menyuarakan opini dan pendapat mereka baik terhadap jalan cerita maupun aktor pemeran film tersebut. Seperti pada penelitian yang dilakukan oleh Antelmi et al. (2018) terhadap tagar - tagar yang muncul seputar penayangan film seri Game Of Thrones yang diproduksi oleh HBO. Penelitian tersebut mendapati adanya penggunaan tagar yang terbentuk secara alami berdasarkan nama atau singkatan film seperti \#gameofthrones dan \#got. Ada pula tagar yang dinisiasi oleh HBO sebagai kampanye promosi serial tersebut seperti \#winterishere dan \#prepareforwinter. Selanjutnya terdapat pula tagar yang digunakan oleh para penggemar serial Game of Thrones untuk menyuarakan respon dan harapan mereka terhadap jalan cerita seperti \#thronesyall. Opini digital yang tersampaikan melalui tagar - tagar tersebut dapat menjadi masukan bagi produser film untuk melakukan pengembangan cerita serta sebagai sarana promosi dengan biaya yang tidak mahal.

Social Network Analysis (SNA)

Social Network Analysis (SNA), yaitu metode untuk menganalisa dan menggambarkan struktur dari jaringan sosial. Metode SNA ini dapat diterapkan baik pada level micro dan level macro (Gruzd, Paulin, \& Haythornthwaite, 2016). Pengukuran pada level micro lebih menitikberatkan pada jaringan komunikasi, yaitu pola relasi dan hubungan yang terbentuk melalui alur penyampaian pesan oleh komunikator - komunikator yang terdapat dalam ruang dan waktu tertentu (Eriyanto, 2014).

Pada level micro analisa lebih melihat fenomena dari sisi komunikator yang disebut juga sebagai aktor pada sebuah jaringan komunikasi, di mana aktor digambarkan sebagai node dan relasi yang terbentuk antar aktor digambarkan sebagai edge. Pada media sosial, node adalah akun - akun media sosial, dan edge adalah relasi yang terbentuk diantara akun tersebut. Contoh edge atau relasi yang terbentuk dalam media sosial adalah mentions, tag, reply, retweet, dan repost (Eriyanto, 2014).

Pada sebuah jaringan komunikasi yang terdapat pada media sosial seperti Twitter, terdapat dua macam jaringan berdasarkan jenis relasi para aktor, yakni jaringan nama (name network) dan jaringan rantai (chain network). Jaringan nama adalah jaringan komunikasi yang ketika aktor saling mention aktor - aktor lainnya pada pesan yang di posting. Sedangkan jaringan rantai atau yang dikenal juga dengan "who replies to whom" adalah jaringan komunikasi yang terbentuk dari perilaku posting dari aktor - aktor yang ada pada media sosial. Jaringan rantai 
pada media sosial dapat terbentuk dari aktivitas reply sebuah pesan (Gruzd, Mai, \& Kampen, 2016).

\section{METODOLOGI}

Penelitian ini mengambil dataset tagar \#TrueBeauty dari Twitter melalui software Netlytic dengan rentang waktu mulai tanggal 30 Januari - 6 Februari 2020. Rentang waktu tersebut digunakan karena bertepatan dengan waktu posting @Webtoon mengenai cast drama True Beauty dan bertepatan pula dengan plot episode cerita komik yang semakin menarik pada Webtoon.

Pengambilan data ini juga menggunakan query yang lebih spesifik, tidak hanya menggunakan kata kunci tagar \#TrueBeauty tetapi juga mengambil semua tweet yang mengandung kata kata Webtoon. Setelah data terkumpul, maka dilakukan pengukuran pada 2 jenis jaringan komunikasi yaitu name network dan chain network yang dapat digambarkan dan dianalisa dengan Netlytic. Selanjutnya dilakukan analisa pada dua level jaringan, yaitu level micro dan macro menggunakan Netlytic. Pada level micro akan melihat fenomena dari sisi aktor dengan mengukur degree centrality yang menunjukkan popularitas aktor dalam sebuah jaringan komunikasi. Popularitas aktor akan dilihat dari jumlah relasi ditujukan kepada aktor tersebut atau disebut juga dengan indegree dan jumlah relasi yang ditujukan oleh aktor tersebut kepada aktor - aktor lain atau disebut juga dengan outdegree (Gruzd et al., 2016).

Sedangkan pada level macro akan dilakukan pengukuran dan analisa pada struktur jaringan sosial yaitu meliputi diameter, density, reciprocity, centralization dan modularity (Eriyanto, 2014; Gruzd et al., 2016). Setelah melakukan analisa pada jaringan komunikasi, maka akan dilakukan pula analisa teks pada pesan untuk mengindentifikasi kata - kata apa saja yang sering digunakan dan juga untuk mengkategorisasikan pesan berdasarkan kata kunci tertentu. Analisa teks ini dilakukan untuk mengetahui trend dan pola pesan yang terdapat pada sebuah jaringan komunikasi (Harder, Howard, \& Rehberg Sedo, 2015).

\section{HASIL DAN PEMBAHASAN}

Dataset dari Netlytic yang berhasil dikumpulkan pada penelitian ini kemudian di filter untuk data cleaning dan menghasilkan 1.591 records. Adapun jenis jaringan yang dapat dianalisa pada Netlytic adalah name network dan chain network dengan data struktur jaringan yang dapat dilihat pada tabel 1 dan 2. Analisa pada level macro dilakukan dengan membandingkan struktur jaringan name network dan chain network, namun untuk level micro hanya akan difokuskan kepada clusters dan aktor yang terdapat pada name network dikarenakan terdapat lebih banyak data aktor yang mempunyai relasi (posters with ties) yaitu sejumlah 1.311. Sedangkan untuk chain network hanya memiliki 20 posters with ties. Adapun sosiogram Name Network dapat dilihat pada Gambar 2. 
Gambar 2. Sosiogram Name Network

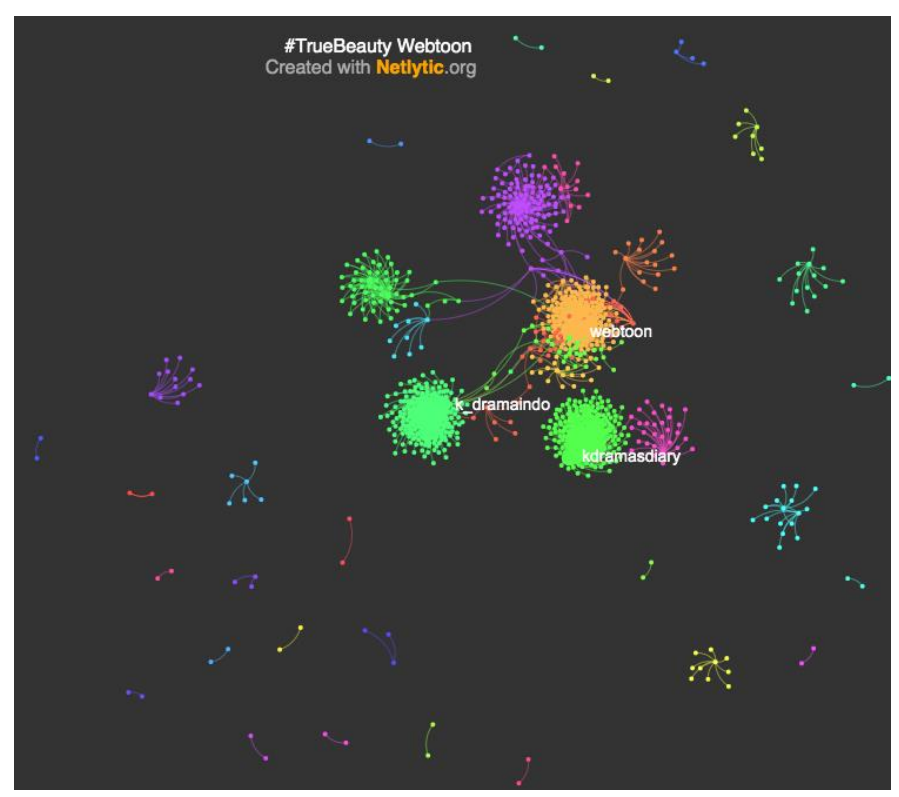

Sumber: Data hasil analisis menggunakan Netlytic

Tabel 1. Struktur Jaringan Name Network

\begin{tabular}{l|c}
\multicolumn{1}{c|}{ Analisis } & Data \\
\hline Diameter & 23 \\
\hline Density & 0.000786 \\
\hline Reciprocity & 0.000000 \\
\hline Centralization & 0.118800 \\
\hline Modularity & 0.784000 \\
\hline
\end{tabular}

Sumber: Data hasil analisis menggunakan Netlytic

Tabel 2. Struktur Jaringan Chain Network

\begin{tabular}{l|c}
\multicolumn{1}{c|}{ Analisis } & Data \\
\hline Diameter & 6 \\
\hline Density & 0.038330 \\
\hline Reciprocity & 0.000000 \\
\hline Centralization & 0.320700 \\
\hline Modularity & 0.331800 \\
\hline
\end{tabular}

Sumber: Data hasil analisis menggunakan Netlytic

Dalam struktur name network terlihat bahwa diameter jaringan memiliki nilai yang tinggi yaitu 23. Hal ini menunjukkan bahwa jaringan tagar \#TrueBeauty merupakan jaringan dengan 
persebaran pesan yang luas dan dapat menjangkau berbagai kalangan. Jaringan tagar \#TrueBeauty yang luas tersebut tentunya menguntungkan bagi Webtoon dan produser film untuk semakin mempopulerkan digital campaign film yang akan dibuat. Adapun struktur name network terbentuk berdasarkan aktivitas mention dan retweet untuk memberikan opini. Sedangkan pada struktur chain network jaringan tagar \#TrueBeauty memiliki diameter yang relatif lebih rendah yaitu 6. Struktur chain network terbentuk berdasarkan aktivitas reply yang dilakukan untuk menjawab pertanyaan aktor mengenai cast film True Beauty. Perbandingan diameter name network dan chain network tersebut menunjukkan bahwa gerakan opini digital akan lebih luas jika tidak di komando oleh aktor - aktor tertentu, dalam hal ini opini mengenai cast True Beauty tersebar lebih luas dengan aktivitas mention dan retweet yang dilakukan secara bebas dibandingkan dengan aktivitas reply kepada pertanyaan yang diajukan atau diinisiasi oleh para aktor dominan.

Selanjutnya untuk density pada kedua jenis jaringan baik pada name network dan chain network relatif rendah yaitu 0.000786 dan 0.038330 , dan untuk reciprocity kedua jaringan juga menunjukkan angka 0 . Hal ini menunjukkan interaksi yang rendah diantara aktor pada jaringan \#TrueBeauty, di mana para aktor hanya melakukan aktivitas mention, retweet dan reply secara satu arah kepada aktor - aktor dominan untuk memberikan opini mengenai cast dari film \#TrueBeauty. Sedangkan aktor - aktor dominan tersebut tidak melakukan reply atau mention sebagai respon terhadap interaksi yang diberikan. Para aktor - aktor lain juga cenderung untuk tidak saling melakukan interaksi atau berdiskusi satu dengan yang lainnya. Hal tersebut menunjukkan bahwa gerakan opini digital pada tagar \#TrueBeauty lebih termotivasi oleh penggunaan tagar untuk tujuan reaching yaitu menyampaikan pesan hanya pada target yang spesifik, yaitu aktor - aktor dominan seperti @webtoon dan @kdramasdiary.

Kemudian dapat dilihat bahwa centralization pada name network memiliki nilai 0.118800 yang relatif lebih rendah dibandingkan dengan chain network yang memiliki nilai 0.320700 . Artinya pada name network gerakan opini digital cukup bebas tersebar pada jaringan tanpa terpusat pada aktor - aktor tertentu. Meskipun akun @webtoon yang merupakan akun resmi dari Webtoon telah menginisiasi pertanyaan mengenai dream cast dari film drama True Beauty, namun akun @webtoon tidak menjadi satu-satunya aktor dominan dan menjadi pusat dari jaringan, bahkan terdapat aktor - aktor dominan lain yang juga yang ikut melakukan tweet serupa dan mendapatkan lebih banyak mentions dan retweet seperti @kdramasdiary dan @k_dramaindo. Hal ini juga berdampak pada modularity yang tinggi untuk name network yaitu 0.784000 dan modularity yang lebih rendah untuk chain network yaitu 0.331800 . Tingginya modularity pada name network menunjukkan bahwa banyak aktor - aktor dominan lain yang tersebar dalam banyak clusters yang berbeda dengan topik percakapan yang berbeda seperti terlihat pada tabel 3 dan pada gambar 2. Data tersebut menunjukkan bahwa tagar \#TrueBeauty telah berhasil menggerakan opini banyak penggemar dari berbagai kalangan dan ada kecenderungan para aktor berusaha menunjukkan eksistensi mereka sebagai penggemar yang selalu up to date mengikuti trend dengan berinisiatif memulai percakapan dengan memberikan opini seputar cast dari film True Beauty. Motivasi ini sesuai dengan yang digagaskan oleh Rauschnabel et al. (2019) bahwa salah satu tujuan penggunaan tagar adalah trendgaging.

Seperti terlihat pada tabel 3 bahwa setiap cluster memiliki satu atau lebih aktor dominan. Semakin besar total degree maka semakin dominan aktor tersebut. Pada tabel 3 terlihat pula bahwa aktor - aktor dominan pada tiap cluster memiliki jumlah indegree yang lebih besar dari jumlah outdegree. Jumlah indegree yang tinggi merupakan indikasi kepopuleran aktor dalam sebuah jaringan komunikasi (Gruzd et al., 2016). Di era media sosial, aktor - aktor populer tersebut berperan sebagai influencers yaitu mereka yang dianggap bisa memberikan pengaruh dengan jumlah followers, like, mentions, retweet yang tinggi dalam sebuah jaringan 
(Ioanid, Militaru, \& Mihai, 2015). Tagar \#TrueBeauty telah berhasil menarik para influencers dari berbagai budaya dan letak geografis yang berbeda. Untuk akun @webtoon sendiri merupakan akun resmi dari Webtoon yang berasal dari Korea Selatan, namun akun tersebut menggunakan bahasa Inggris sehingga dapat menjangkau para penggemar di berbagai belahan dunia. Sedangkan influencers lain yang ada di dalam jaringan tagar \#TrueBeauty justru berasal negara - negara lain seperti @k_dramaindo yang merupakan akun fanbase drama Korea di Indonesia dan menggunakan bahasa Indonesia. Selanjutnya terdapat juga aktor dominan dari Thailand, yaitu @jiyeonie0819 yang menggunakan bahasa Thailand pada semua tweet yang terkait dengan film drama Korea termasuk True Beauty. Dalam gerakan opini digital, keterlibatan influencers tentunya sangat bermanfaat dalam memfasilitasi penggemar dari berbagai latar belakang untuk menyampaikan opini dengan nyaman pada komunitas atau kelompok jaringan yang dekat dan memiliki banyak kesamaan (Rosenthal, 2015). Hal tersebut sesuai dengan salah satu motivasi penggunaan tagar yaitu bonding, untuk terkoneksi dengan pengguna lain yang memiliki banyak kesamaan (Rauschnabel et al., 2019).

Tabel 3. Aktor - Aktor Dominan Pada Name Network

\begin{tabular}{l|l|l|l|l} 
Clusters & Aktor dominan & Indegree & Outdegree & Total Degree \\
\hline Cluster 1 & kdramasdiary & 334 & 0 & 334 \\
Cluster 2 & k_dramaindo & 323 & 0 & 323 \\
Cluster 3 & webtoon & 306 & 0 & 306 \\
Cluster 4 & jiyeonie0819 & 109 & 1 & 110 \\
Cluster 5 & ygofficialblink & 53 & 0 & 53 \\
& blinkdara & 53 & 0 & 53 \\
Other Clusters & humanluxurychu & 16 & 0 & 16 \\
& xuerendipity & 30 & 0 & 30 \\
& blackpinkbiatch & 10 & 0 & 10 \\
& 8l715121000 & 11 & 0 & 11 \\
& nufilm456 & 13 & 0 & 13 \\
& gabueiu & 12 & 0 & 12 \\
& twinkyystar & 18 & 0 & 18 \\
& huyentrang1987 & 4 & 5 & 9 \\
\hline
\end{tabular}

Sumber: Data hasil analisis menggunakan Netlytic

\section{Text Analysis}

Pada jaringan tagar \#TrueBeauty terdapat beberapa kata yang populer digunakan pada tweet pengguna (tabel 4). Dari kumpulan kata - kata populer tersebut, dapat dilihat bahwa kata yang sering digunakan adalah kata - kata yang berhubungan dengan pertanyaan siapa yang cocok untuk memerankan drama True Beauty, seperti kata "cast", "drama", "ideal", dan "siapa". Setelah ditelusuri lebih lanjut, ternyata kata - kata tersebut banyak muncul pada retweet pertanyaan yang diajukan oleh aktor - aktor dominan mengenai cast True Beauty. Sebagai contoh adalah tweet @kdramasdiary yang terlihat pada Gambar 3. 


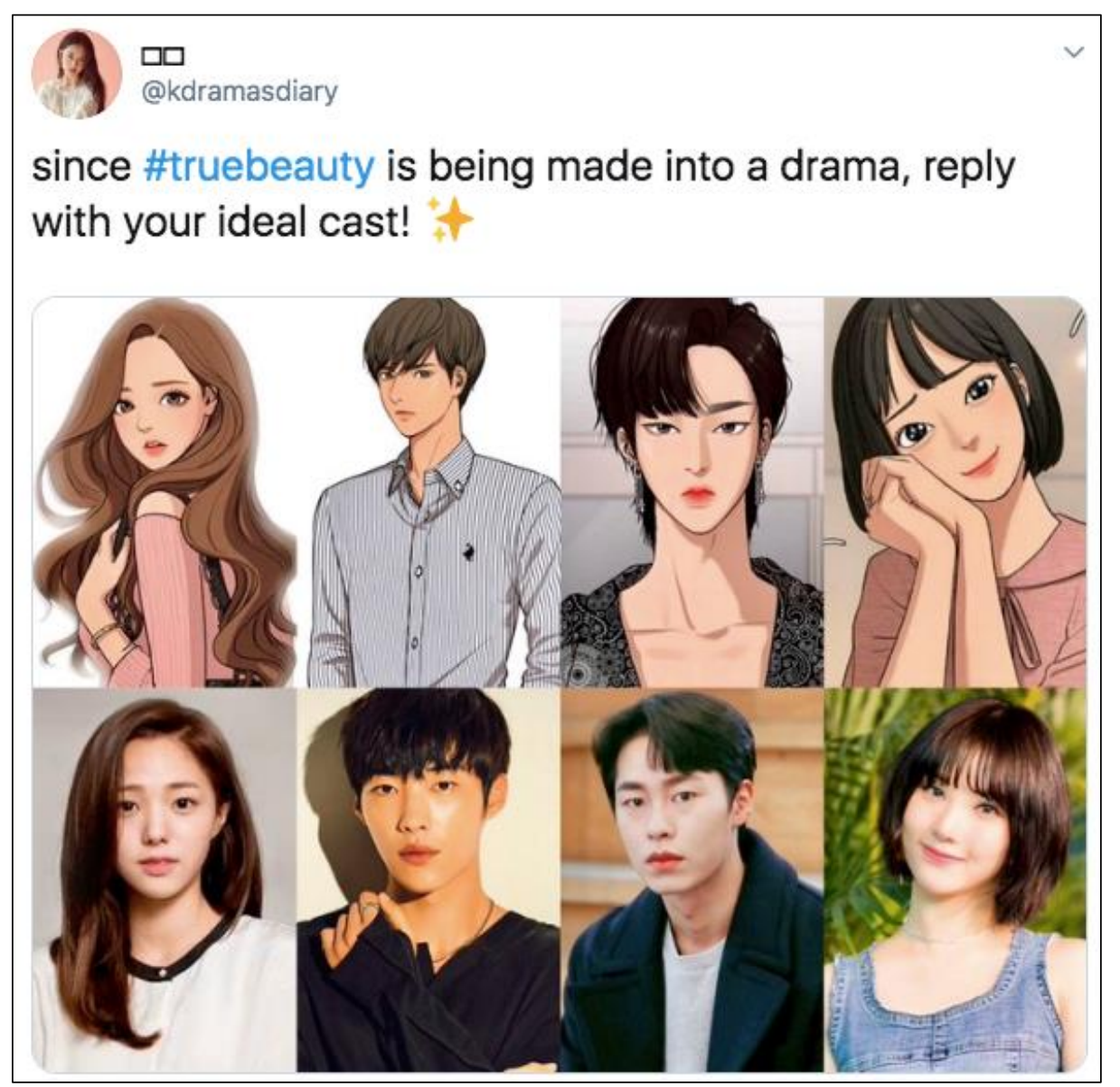

Sumber Gambar: Twitter.com/kdramasdiary

Tweet tersebut mendapatkan retweets sebanyak 334 kali dan telah muncul juga sebagai kata populer dalam bentuk short URL https://t.co/VuvHuBTRmI.

Tingginya jumlah retweet dalam jaringan tagar \#TrueBeauty menandakan bahwa banyak aktor - aktor yang lebih memilih untuk melakukan retweet daripada reply. Salah satu motif pengguna melakukan retweet adalah untuk mendapatkan feedback dari para (Abdullah, Nishioka, Tanaka, Murayama, \& College, 2017). Banyaknya retweet pesan yang berisi pertanyaan mengenai cast True Beauty tersebut menandakan bahwa banyak aktor - aktor yang lebih ingin menjadi perpanjangan tangan untuk menyampaikan pesan dari aktor dominan, dengan tujuan lebih kepada untuk memulai diskusi atau mengetahui pendapat dari aktor - aktor lain mengenai cast film tersebut daripada melakukan reply untuk memberikan opini mereka. Dalam gerakan opini digital, hal ini sangat bermanfaat dalam pembentukan clusters baru yang terdiri dari aktor - aktor dengan opini yang beragam. Tentunya diskusi diskusi dalam clusters tersebut juga dapat memperpanjang usia tagar \#TrueBeauty pada jaringan komunikasi penggemar. 
Tabel 4. Kata - Kata Populer Dalam Jaringan Tagar \#TrueBeauty

\begin{tabular}{l|l|l} 
No & Kata - Kata & Jumlah \\
\hline 1 & \#TrueBeauty & 1592 \\
\hline 2 & Cast & 687 \\
\hline 3 & drama & 684 \\
\hline 4 & webtoon & 431 \\
\hline 5 & reply & 344 \\
\hline 6 & pemainnya & 335 \\
\hline 7 & made & 335 \\
\hline 8 & ideal & 334 \\
\hline 9 & https://t.co/VuvHuBTRmI & 334 \\
\hline 10 & siapa & 322 \\
\hline
\end{tabular}

Selanjutnya text analysis dilakukan untuk mendapatkan kategorisasi pesan berdasarkan kata - kata tertentu. Kategorisasi pesan didasarkan pada nama karakter pada komik True Beauty dan berdasarkan nama aktor dan artis yang direkomendasikan oleh penggemar untuk menjadi cast film tersebut. Hasil dari kategorisasi tersebut dapat dilihat pada tabel 5 dan tabel 6.

Tabel 5. Kategori Pesan Berdasarkan Nama Karakter

\begin{tabular}{l|l|l|l} 
No & Nama Karakter & Posts & Terms \\
\hline 1 & Im Jugyung & 118 & 176 \\
\hline 2 & Han Seojun & 78 & 81 \\
\hline 3 & Lee Suho & 74 & 103 \\
\hline
\end{tabular}

Tabel 6. Kategori Pesan Berdasarkan Nama Aktor

\begin{tabular}{l|l|l|l} 
No & Nama aktor & Posts & Terms \\
\hline 1 & Blackpink's Jisoo & 157 & 470 \\
\hline 2 & Astro's Cha Eunwoo & 77 & 227 \\
\hline 3 & Kwon Hyunbin & 36 & 83 \\
\hline
\end{tabular}

Dapat dilihat pada tabel 5 dan 6 bahwa nama karakter yang paling banyak disebut adalah Im Jugyung dengan nama aktris yang banyak direkomendasikan oleh penggemar adalah Jisoo dari sebuah girl group Korea bernama Blackpink. Banyak para penggemar yang merasa bahwa Jisoo sangat cocok untuk memerankan Jugyung baik dari penampakan visual maupun kepribadiannya yang ceria. Penulis komik Webtoon True Beauty, Yaongyi, juga telah memilih Jisoo sebagai pemeran Jugyung ("Jisoo BLACKPINK Dikabarkan Akan Terlibat Dalam Sebuah Drama Korea, Debut Jadi Artis? - Pos Kupang," 2019). Selain itu terdapat pula petisi online pada Change.org yang telah ditandatangani oleh lebih dari 9000 pendukung untuk Jisoo dapat memerankan Jugyung ("Tandatangani Petisi," n.d.). Meskipun demikian belum ada keputusan resmi terutama dari YG Entertainment, sebagai pihak manajemen Blackpink apakah Jisoo dapat menerima peran tersebut. Hal ini tentunya dikuatirkan oleh para penggemar, apalagi YG Entertainment sendiri dikenal sebagai manajemen yang ketat dalam mengatur artis - artisnya (Lew, 2019). Pada jaringan tagar \#TrueBeauty para penggemar dapat secara langsung menargetkan opini mereka dengan mention @webtoon dan @ygofficialblink sebagai akun resmi dari Webtoon dan YG Entertainment, seperti yang terlihat pada tweet oleh @duyoungit: 
“@webtoon Please cast Blackpink Jisoo as a main lead please... even if YG doesn't allow her just take her from her company and kidnap her... but please cast jisoo as a main character..For \#TrueBeauty @webtoon @ygofficialblink"

Hal ini menunjukkan bahwa media sosial seperti Twitter merupakan sarana yang tepat bagi gerakan opini digital untuk menyampaikan opini secara langsung kepada pihak yang dituju tanpa harus terdapat mediasi berupa institusi resmi atau lembaga survey. Selain itu opini yang disampaikan dalam gerakan pini digital juga lebih mewakili perasaan dan emosi spontan dari peggemar tanpa harus mengkhawatirkan tata bahasa dan tata krama dalam penyampaian opini (Barisione \& Ceron, 2017). Hal ini dapat terlihat dari tweet @duyoungit yang menyampaikan bahwa lebih baik Jisoo diculik dari YG Entertainment untuk berperan sebagai Jugyung. Kemudian hal itu dapat dilihat juga pada tweet oleh @rivera_caryle yang melakukan retweet dari @znyuu_yang berbunyi:

“@webtoon FIXXXXXX!! @ygofficialblink @yg_stage
\#JisooForTrueBeauty \#JISOOFORTRUEBEAUTY
https://t.co/KXIVoNyKRo"

Pada tweet oleh @rivera_caryle tersebut dapat dilihat penggunaan huruf kapital berulang ulang yang menunjukkan emosi dari penulis tweet tersebut.

\section{KESIMPULAN}

Jaringan komunikasi tagar \#TrueBeauty pada Twitter terbentuk dari gerakan opini digital para penggemar komik Webtoon True Beauty untuk menyampaikan pendapat mereka tentang artis yang pantas untuk memerankan film adaptasi komik tersebut. Adapun secara struktur jaringan, dapat disimpulkan bahwa dalam menyampaikan opininya, para aktor dalam jaringan cenderung menggunakan retweet dan mention daripada reply langsung kepada akun - akun dominan yang membahas topik tersebut. Meskipun akun @webtoon telah mengawali gerakan opini digital ini dengan memberikan pertanyaan siapa pemeran yang pantas untuk film True Beauty, namun penyampaian opini tidak terpusat hanya kepada @webtoon, namun juga kepada banyak aktor - aktor dominan lainnya seperti @kdramasdiary dan @k_dramaindo. Opini digital tagar \#TrueBeauty juga tersebar luas ke berbagai negara dan latar belakang budaya yang beragam yang kemudian membentuk clusters atau kelompok - kelompok penggemar yang berbeda. Peran influencers atau aktor - aktor dominan sangat penting dalam penyebaran opini ke dalam masing - masing lingkup komunitas yang berbeda dengan menggunakan bahasa dan cara penyampaian yang bisa diterima oleh budaya komunitas tersebut.

Text analysis menghasilkan data bahwa kata - kata yang sering disebut dalam tweet adalah Jisoo Blackpink dengan banyak sekali mention yang ditujukan langsung kepada @ygofficialblink sebagai akun resmi pihak manajemen Blackpink untuk mengijinkan Jisoo memerankan tokoh utama dalam True Beauty. Hal ini menunjukkan bahwa industri perfilman ataupun manajemen artis tidak boleh menganggap sepele opini para penggemar yang disampaikan pada media sosial karena penggemar lebih suka menghimpun opini dan menyampaikan perasaan serta emosi mereka terhadap idolanya secara spontan melalui media sosial. 


\section{DAFTAR PUSTAKA}

Abdullah, N. A., Nishioka, D., Tanaka, Y., Murayama, Y., \& College, T. (2017). Why I Retweet? Exploring User's Perspective on Decision-Making of Information Spreading during Disasters. 10.

Antelmi, A., Breslin, J., \& Young, K. (2018). Understanding User Engagement with Entertainment Media: A Case Study of the Twitter Behaviour of Game of Thrones (GoT) Fans. 2018 IEEE Games, Entertainment, Media Conference (GEM), 1-9. https://doi.org/10.1109/GEM.2018.8516505

Barisione, M., \& Ceron, A. (2017). A Digital Movement of Opinion? Contesting Austerity Through Social Media. In M. Barisione \& A. Michailidou (Eds.), Social Media and European Politics (pp. 77-104). https://doi.org/10.1057/978-1-137-59890-5_4

Bernard, A. (2019). Theory of the Hashtag. John Wiley \& Sons.

Eriyanto. (2014). Analisis Jaringan Komunikasi: Strategi Baru dalam Penelitian Ilmu Komunikasi dan Ilmu Sosial Lainnya. Jakarta: Prenadamedia Group.

Find Out Koreans Desired Cast For Adaptation Of Popular Webtoon “True Beauty." (2019, January 17). Retrieved March 25, 2020, from Kpopmap website: https://www.kpopmap.com/find-out-koreans-desired-cast-for-remake-of-popularwebtoon-true-beauty/

Gruzd, A., Mai, P., \& Kampen, A. (2016). The SAGE Handbook of Social Media Research Methods (By pages 513-529). https://doi.org/10.4135/9781473983847

Gruzd, A., Paulin, D., \& Haythornthwaite, C. (2016). Analyzing Social Media and Learning Through Content and Social Network Analysis: A Faceted Methodological Approach. Journal of Learning Analytics, 3(3), 46-71. https://doi.org/10.18608/jla.2016.33.4

Harder, A., Howard, V., \& Rehberg Sedo, D. (2015). Creating Cohesive Community Through Shared Reading: A Case Study of One Book Nova Scotia. Partnership: The Canadian Journal of Library and Information Practice and Research, 10(1). https://doi.org/10.21083/partnership.v10i1.3098

Ioanid, A., Militaru, G., \& Mihai, P. (2015). Social Media Strategies For Organizations Using Influencers' Power. European Scientific Journal, 5.

Jisoo BLACKPINK Dikabarkan Akan Terlibat Dalam Sebuah Drama Korea, Debut Jadi Artis? Pos Kupang. (2019). Retrieved March 26, 2020, from https://kupang.tribunnews.com/2019/04/01/jisoo-blackpink-dikabarkan-akanterlibat-dalam-sebuah-drama-korea-debut-jadi-artis

Lew. (2019). Things That Trainees Need To Give Up To Be A Part Of YG, As Told By YG Artists. Retrieved March 26, 2020, from Soompi website: https://www.soompi.com/article/1286887wpp/things-trainees-need-give-part-ygtold-yg-artists

Popular Mobile Webcomic Service, LINE Webtoon, Debuts in the United States and Worldwide-MarketWatch. (2014). Retrieved March 26, 2020, from https://www.marketwatch.com/press-release/popular-mobile-webcomic-serviceline-webtoon-debuts-in-the-united-states-and-worldwide-2014-07-02 
Ranjan, S., \& Sood, S. (2018). Analyzing Social Media Community Sentiment Score for Prediction of Success of Bollywood Movies. 10.

Rauschnabel, P. A., Sheldon, P., \& Herzfeldt, E. (2019). What motivates users to hashtag on social media? Psychology \& Marketing, 36(5), 473-488. https://doi.org/10.1002/mar.21191

Rosenthal, S. (2015). Detecting influencers in social media discussions. XRDS: Crossroads, The ACM Magazine for Students, 21(1), 40-45. https://doi.org/10.1145/2659889

Tandatangani Petisi. (n.d.). Retrieved March 26, 2020, from Change.org website: https://www.change.org/p/blackpink-ygmail-net-jisoo-for-true-beauty-626bc3cc1591-4a0c-b208-acaab207fc1b

Tantimedh. (2019, September 2). WEBTOON is the World's Most Successful Comics Publisher - And You Hadn't Heard of it Till Now. Retrieved March 26, 2020, from Bleeding Cool News And Rumors website: https://www.bleedingcool.com/2019/09/02/webtoonis-the-worlds-most-successful-comics-publisher-and-you-hadnt-heard-of-it-tillnow/

15 Dramas Of 2020 Based On Webtoon-Confirmed. (2020, February 13). Retrieved March 26, 2020, from Kpopmap website: https://www.kpopmap.com/14-dramas-of-2020based-on-webtoon/

24 Dramas Of 2019 Based On Webtoon. (2019, August 1). Retrieved March 26, 2020, from Kpopmap website: https://www.kpopmap.com/23-dramas-of-2019-based-onwebtoon/ 